\title{
Preliminary assessment of pseudo-total and bioavailable metals in depth in the sediment of Luíz Rau stream in Novo Hamburgo (RS)
}

\author{
C. L. Ávila ${ }^{a *}$, L. Bianchin ${ }^{a}$ and J. C. Illi \\ anstituto de Ciências Exatas e Tecnológicas, Universidade Feevale, Rodovia RS 239, 2755 , \\ CEP 93352-000, Novo Hamburgo, RS, Brazil \\ *e-mail: avilanh@gmail.com
}

Received: January 17, 2015 - Accepted: May 20, 2015 - Distributed: November 30, 2015

(With 3 figures)

\begin{abstract}
The Luíz Rau stream is one of the main streams of Novo Hamburgo. In the stream industrial effluents are released from various sectors, from paint and adhesive industries, metallurgy and leather industry, besides receiving a large amount of domestic sewage. The emissions of these pollutants contribute to decrease water and sediment quality. Within this context, this study evaluated the conditions of the Luíz Rau stream bed sediments, with the determination of the metals like cadmium, lead, chromium and nickel, in depth. To perform the evaluation three points were chosen for sampling along the stream course. The sampling sites were identified as Point A, in Roselândia district and this corresponds to one of the springs and therefore considered as reference value, Point B, in Santo Afonso district being a midpoint of the stream, and Point $\mathrm{C}$ also located in Santo Afonso district, near the outfall in Rio dos Sinos river. Cadmium was not detected in any point. At the $\mathrm{A}$ and $\mathrm{C}$ points chromium was the metal observed in higher concentration in the sediment, up to $45.14 \mathrm{mg} \mathrm{kg}^{-1}$ concentration. In the B point, the metal that was observed in the highest amount was nickel in the concentration of $20.69 \mathrm{mg} \mathrm{kg}^{-1}$.
\end{abstract}

Keywords: sediment, Luíz Rau stream, environmentally available metals, collection of sediment in depth.

\section{Avaliação preliminar de metais pseudo-totais e biodisponíveis em profundidade no sedimento do arroio Luíz Rau em Novo Hamburgo (RS)}

\begin{abstract}
Resumo
O arroio Luíz Rau é um dos principais arroios de Novo Hamburgo, e um importante afluente do Rio dos Sinos. Nele são lançados efluentes industriais dos mais diversos setores, desde indústrias de tintas e adesivos, metalurgia e da indústria do couro, além de receber uma grande quantidade de esgoto doméstico. As emissões destes poluentes contribuem para uma diminuição na qualidade da água e dos sedimentos. Dentro deste contexto, este trabalho avaliou as condições do sedimento do arroio Luíz Rau, com a determinação dos metais cádmio, chumbo, cromo e níquel em profundidade, nas formas pseudo-total e biodisponível. Para a realização desta avaliação, foram escolhidos três pontos para coleta de amostras ao longo do percurso do arroio. Os pontos foram identificados por Ponto A, no bairro Roselândia, sendo que este corresponde a uma das nascentes e por isso considerado como ponto branco, o Ponto B, no bairro Santo Afonso, sendo um ponto intermediário do arroio, e o Ponto C, também localizado no bairro Santo Afonso, próximo à foz, junto ao Rio dos Sinos. O cádmio não foi detectado em nenhum dos pontos amostrados. Nos pontos $\mathrm{A}$ e $\mathrm{C}$, o cromo foi o metal observado em maior concentração no sedimento, com concentração de até $45,14 \mathrm{mg} \mathrm{kg}^{-1}$. Já no ponto B, o metal que foi observado em maior quantidade foi o níquel na concentração de $20,69 \mathrm{mg} \mathrm{kg}^{-1}$.
\end{abstract}

Palavras-chave: sedimento, arroio Luíz Rau, biodisponibilidade de metais, coleta de sedimentos em profundidade.

\section{Introduction}

Sediments in urban areas may be originated from natural or anthropogenic sources. During urban sprawl, the increase in sediment produced by watershed is significant due to the buildings, cleaning of streets and subdivisions and the construction of streets, avenues and highways, among other causes (Poleto, 2008).

Although scarce, the displacements of sediments carried by runoff and other processes end up causing the reassignment and redistribution by the basin of considerable amounts of solid particles to the point where they can eventually change the water quality and certainly affect the use, conservation and management of water resources (Tucci, 2002).

Characterization of fluvial sediments allows the assessment of the environmental impact suffered by a watershed over time (Rodrigues, 2007). The ability of 
sediments to accumulate compounds makes this one of the most important environmental compartments to assess the level of contamination of aquatic environments. The elements indicators of sediment pollution can be either organic, such as herbicides and pesticides, or inorganic, for example, metals (Cotta et al., 2006).

Even after the end of pollutant discharges and improvements in the quality of river water, the contaminated sediment remains a risk factor for biota (Rodrigues, 2007). Some studies have demonstrated the importance of the quantification of metals in sediments, since this compartment may be subject to a dynamic that enables resuspension or release these to the water column, making them bioavailable to organisms in the aquatic environment (Costa and Espíndola, 2000; Siqueira and Braga, 2000; Ishikawa et al., 2009).

Thus, the protection of sediment quality should be seen as an important part in protecting aquatic environments. Although the water and biota do not presents concentrations above the current legislation, the deposited pollutants in sediments pose a risk of degradation to the environment (Yu et al., 2001).

An important feature that distinguishes metals from other toxic pollutants, in addition to its non-biodegradability, is that its toxicity is largely controlled by their physicochemical characteristics. The oxidation state of the metals determines its mobility, bioavailability and even their toxicity (Abreu et al., 2002; Rodrigues, 2007).

The stream bed sediments play a very important role in the pollution of water bodies by metals. They can be used in the assessment of contaminants that do not remain soluble after its release into surface waters. In addition, the sediment particles act as carriers and possible sources of pollution because metals are not constantly connected and they can be rearranged in the water column due to environmental changes such as displacement with higher levels of alkali or alkaline earth salts concentration, changes in Eh values and $\mathrm{pH}$ reduction (Pickering, 1986; Silva, 2002).

Correlation studies between metals and particle size suggest that generally finer particles have higher concentrations of metals and the major portion of metals is embedded in silt and clay fractions (Quináglia, 2006).

The sediment bioavailable fraction is the sum of exchangeable and soluble or easily adsorbed fractions (Magalhães, 2008). The proportion of soluble and exchangeable fractions relative to the total amount is an indicator of the mobility of metal, and therefore its bioavailability (Magalhães, 2008). The occurrence of high concentrations of metals in sediments did not necessarily result in harmful effects to aquatic biota, because many factors can influence its bioavailability and toxicity (Poleto, 2008). Different samples having the same concentration of ions of a metal may vary by a factor of at least ten, in terms of toxicity for organisms associated with the metal (Baird and Cann, 2011).

Thus, this study aims to evaluate the metals presents in pseudo-total (acid-leachable metals that are not part of silicate matrix) and bioavailable forms in the sediment of the Luiz Rau stream, in Novo Hamburgo/RS, at three sample sites along its course.

\section{Material and Methods}

\subsection{Study area}

The Rio dos Sinos watershed is located in the eastern region of the state of Rio Grande do Sul and it is part of the Guaíba hydrographic region, between parallels 29 and 30 degrees south and has an area of $3820 \mathrm{~km}^{2}$, which corresponds to $4.5 \%$ of the watershed of Guaíba and $1.5 \%$ of total area of the state (FEPAM, 2011).

The watershed has an approximate population of 975.000 inhabitants, of which $90.6 \%$ in urban areas and $9.4 \%$ in rural areas. The watercourse is approximately $190 \mathrm{~km}$ and an average annual rainfall of $1.350 \mathrm{~mm}$ (FEPAM, 2011).

Its headwaters are located in the municipality of Caará in Serra Geral upland, $60 \mathrm{~m}$ height (FEPAM, 2011), being its main tributaries Paranhama River, Rio da Ilha River and Rolante River. The whatershed receives contributions from streams Sapiranga, Pampa, Luiz Rau, Gate, João Correa, Sapucaia and others (COMITESINOS, 2011). The characterization of Rio dos Sinos basin is shown in Figure 1.

The Luiz Rau stream has a path of $13 \mathrm{~km}$ in center area of Novo Hamburgo, with industries, trade and houses, reaching at Rio dos Sinos (COMUSA, 2011). The sampling sites were chosen in one of its sources (point A), at an intermediate point (Point B) and near of the mouth of the creek (Point C). The spots were located using a GPS receiver (Garmin E-Trex, with horizontal accuracy 7 to $14 \mathrm{~m}$ ). The identification, location and geographic coordinates of the sites are described in Table 1.

\subsection{Collection and sample preparation}

Two samples at each sample site were collected in the period from February to April 2011, with a core made of PVC pipe $25 \mathrm{~mm}, 20 \mathrm{~cm}$ long, marked at depths of 5, 10 and $15 \mathrm{~cm}$. Samples were collected by introducing the core in the sediment located in stream bed. The cores were frozen for two days. After this step, they were sectioned at 5,10 and $15 \mathrm{~cm}$ marks.

Samples of the various layers of each point were oven dried at a temperature of $50^{\circ} \mathrm{C}$ and after milled and sieved through a sieve of $1 \mathrm{~mm}$ mesh. The material of less than $1 \mathrm{~mm}$ grain size was used for the determination of $\mathrm{pH}$, organic matter and CEC (cation exchange capacity) as described in Tedesco et al. (1995) as well as the physical fractionation (EMBRAPA, 1997). For determination of the metals in the pseudo-total and bioavailable forms, the samples were subjected to additional milling to homogenization and particle size reduction $(\leq 62 \mu \mathrm{m})$.

Table 1. Identification, geographical location and coordinates of the sampled points.

\begin{tabular}{ccc}
\hline $\begin{array}{c}\text { Point of } \\
\text { Collection }\end{array}$ & Latitude & Longitude \\
\hline Point A & $29^{\circ} 39^{\prime} 30.0^{\prime \prime}$ South & $51^{\circ} 08^{\prime} 38.1^{\prime \prime}$ West \\
Point B & $29^{\circ} 43^{\prime} 03.1^{\prime}$ South & $51^{\circ} 07^{\prime} 55.9^{\prime}$ West \\
Point C & $29^{\circ} 43^{\prime} 47.6^{\prime \prime}$ South & $51^{\circ} 07^{\prime} 35.3^{\prime}$ West \\
\hline
\end{tabular}


LEGEND

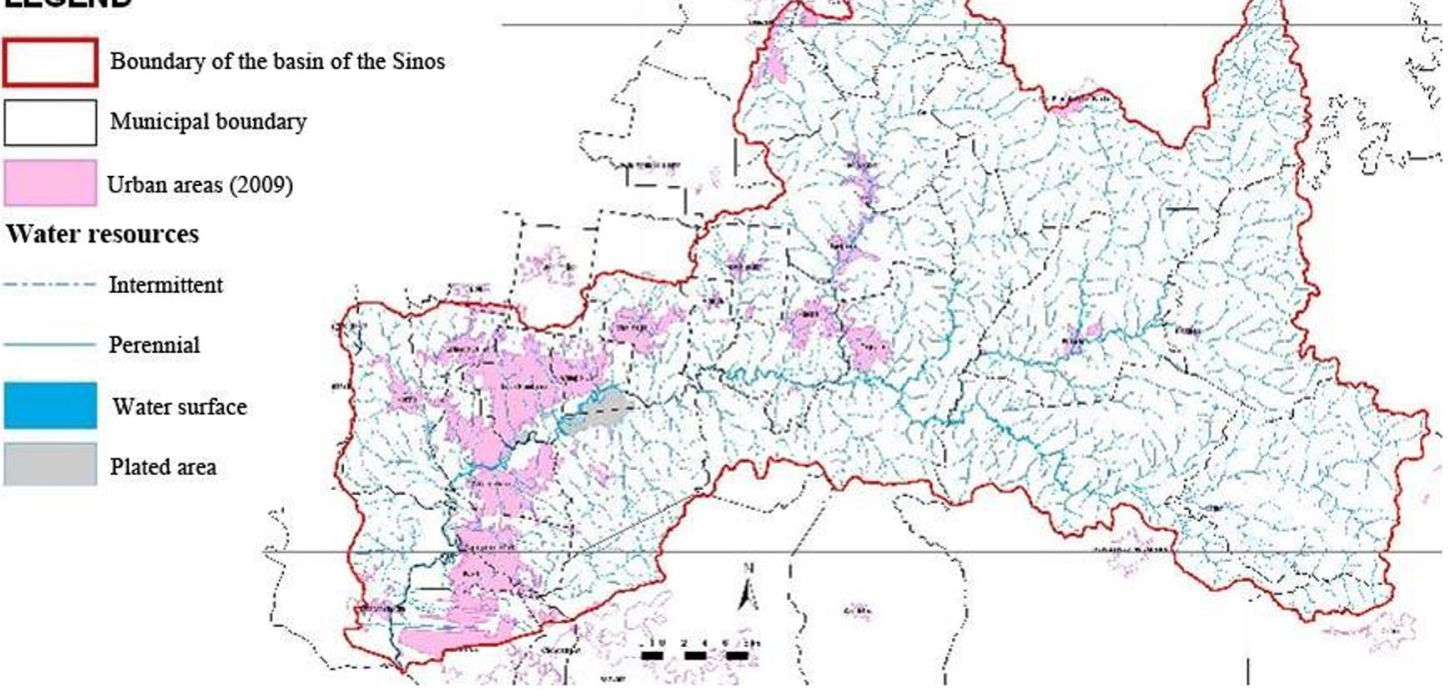

Figure 1. Characterization of Sinos River Basin. Source: COMITESINOS (2011).

\subsection{Analytical determinations}

The determination of ions (calcium, magnesium, aluminum, manganese, potassium and sodium), organic matter and $\mathrm{pH}$ were performed according to methods presented by Tedesco et al. (1995). For the determination of pseudo-total metals the methodology used was 3050B (EPA, 1996) and for determining the bioavailable metals was applied a methodology based in Tedesco et al. (1995) and Mozeto et al. (2003), which consists in the extraction of metals from sediment with hydrochloric acid solution, stirred for $2 \mathrm{~h}$ and centrifugation of the supernatant. The subsequent detection of metals was performed by flame atomic absorption spectrophotometry (FAAS) using the equipment Spectra AA, model 110 (Varian, USA). Analytical grade reagents were used throughout. All containers and glassware were soaked in $3 \mathrm{~mol} \mathrm{~L}^{-1}$ nitric acid for at least $24 \mathrm{~h}$ and rinsed with distilled, deionized water with a resistivity of $18 \mathrm{M} \Omega \mathrm{cm}$ from Millipore water purification system (Millipore, MA, USA). The same quality water was used for the preparation of samples and standards. The calibration solutions of metals were prepared from a $1000 \mathrm{mg} \mathrm{L}^{-1}$ stock solution (Titrisol/Merck).The working standards were prepared by serial dilutions of the stock solution. Results were compared with the resolution 344/04 CONAMA (Brasil, 2004) which determines parameters for metals in dredging the bottom of rivers, lakes materials, etc.

\section{Results}

The percentages of size fractions of the sampled points in each layer of the sediment are shown in Table 2. The sediment grain size is of fundamental importance for the evaluation of their features because the granules of different sizes have different adsorption capacities of metals in water resources (Poleto, 2008). Importantly, clay and silt
Table 2. Particle size characterization of sediment samples.

\begin{tabular}{ccccc}
\hline \multirow{2}{*}{ Points } & Depth & Clay & Silt & Sand \\
\cline { 2 - 5 } & $\mathbf{c m}$ & & $\mathbf{\%}$ & \\
\hline Point A & 5 & 3.0 & 0.5 & 96.5 \\
& 10 & 3.5 & 0.3 & 96.2 \\
& 15 & 3.4 & 1.8 & 94.7 \\
Point B & 5 & 4.3 & 0.3 & 95.4 \\
& 10 & 4.2 & 2.1 & 93.7 \\
& 15 & 13.5 & 9.2 & 77.3 \\
Point C & 5 & 5.0 & 5.8 & 89.3 \\
& 10 & 4.8 & 12.0 & 83.2 \\
& 15 & 5.5 & 0.9 & 93.5 \\
\hline
\end{tabular}

fractions are those with greater ability to adsorb metals, since they have a smaller particle size (Bocalon, 2007).

The characterization of sediment samples is shown in Table 3. The bioavailability of metals is linked to CEC (cation exchange capacity) and this depends on several factors such as the type of clay-mineral present in the sediment, its quantity and also the organic matter content, and more clayey sediments have higher CEC values (Poleto and Merten, 2006).

At Table 4 results of pseudo-total and bioavailable metals in all sampled points and depths are presented. Cadmium was not found within the limits of detection of $0.0305 \mathrm{mg} \mathrm{kg}^{-1}$.

\section{Discussion}

Analyzing the data at Table 2 it is possible to observe that point $\mathrm{B}$ at the depth of $15 \mathrm{~cm}$ have a higher concentration of clay and silt. This characteristic results in an increase of CEC, meaning that there is a predominance of negative surface charges and greater ability to bind with organic matter 
Table 3. Chemical characterization of sediment samples (mean values) - Luiz Rau stream, RS.

\begin{tabular}{|c|c|c|c|c|c|c|c|c|c|}
\hline \multirow{3}{*}{ Parameter } & \multicolumn{3}{|c|}{ Point A } & \multicolumn{3}{|c|}{ Point B } & \multicolumn{3}{|c|}{ Point C } \\
\hline & 5 & 10 & 15 & 5 & 10 & 15 & 5 & 10 & 15 \\
\hline & & & & & $\mathbf{c m}$ & & & & \\
\hline Potassium $\left(\mathrm{mg} \mathrm{dm}^{-3}\right)$ & 110.0 & 130.0 & 130.0 & 109.5 & 98.0 & 127.0 & 431.0 & 206.0 & 107.0 \\
\hline Sodium $\left(\mathrm{mg} \mathrm{dm}^{-3}\right)$ & 105.0 & 101.0 & 86.0 & 32.0 & 32.5 & 35.5 & 66.0 & 53.5 & 59.0 \\
\hline Aluminum $\left(\mathrm{cmol}_{\mathrm{c}} \mathrm{dm}^{-3}\right)$ & 0.12 & 0.12 & 0.18 & 0.17 & 0.18 & 0.35 & 0.13 & 0.14 & 0.15 \\
\hline Calcium $\left(\mathrm{cmol}_{\mathrm{c}} \mathrm{dm}^{-3}\right)$ & 5.50 & 6.30 & 6.35 & 4.15 & 5.02 & 6.83 & 6.21 & 4.83 & 7.09 \\
\hline Magnesium $\left(\mathrm{cmol}_{\mathrm{c}} \mathrm{dm}^{-3}\right)$ & 1.60 & 1.70 & 2.21 & 1.25 & 1.39 & 2.31 & 1.52 & 1.30 & 1.81 \\
\hline Manganese $\left(\mathrm{cmol}_{\mathrm{c}} \mathrm{dm}^{-3}\right)$ & 11.0 & 19.0 & 19.8 & 18.7 & 35.2 & 34.12 & 23.0 & 17.2 & 24.5 \\
\hline $\operatorname{CEC}\left(\mathrm{cmol}_{\mathrm{c}} \mathrm{dm}^{-3}\right)$ & 8.00 & 9.00 & 9.50 & 6.65 & 7.10 & 10.10 & 9.32 & 7.10 & 9.65 \\
\hline Organic Matter (\%) & 0.70 & 1.50 & 1.63 & 2.21 & 0.81 & 0.69 & 2.44 & 1.53 & 2.64 \\
\hline $\mathrm{pH}$ & 7.18 & 6.86 & 6.62 & 6.89 & 6.30 & 5.33 & 6.64 & 6.72 & 6.53 \\
\hline
\end{tabular}

Table 4. Concentration of metals in sediment samples - Luiz Rau stream, RS.

\begin{tabular}{|c|c|c|c|c|c|c|c|}
\hline \multirow{3}{*}{ Point } & \multirow{2}{*}{ Depth } & \multicolumn{2}{|c|}{ Lead } & \multicolumn{2}{|c|}{ Chromium } & \multicolumn{2}{|c|}{ Nickel } \\
\hline & & Pseudo-total & Bioavailable & Pseudo-total & Bioavailable & Pseudo-total & Bioavailable \\
\hline & cm & & 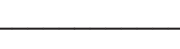 & $-\mathbf{m}$ & $\mathbf{k g}^{-1}$ & & \\
\hline \multirow[t]{3}{*}{$\mathrm{A}$} & 5 & 3.42 & 1.89 & 17.74 & 5.52 & 8.85 & 0.90 \\
\hline & 10 & 13.55 & 4.98 & 20.61 & 6.22 & 11.15 & 1.04 \\
\hline & 15 & 11.73 & 4.99 & 19.97 & 7.55 & 7.92 & 0.98 \\
\hline \multirow[t]{3}{*}{ B } & 5 & 6.38 & 5.03 & 16.38 & 5.48 & 9.20 & 3.77 \\
\hline & 10 & 9.29 & 5.97 & 17.02 & 4.71 & 20.69 & 1.69 \\
\hline & 15 & 13.04 & 5.65 & 17.82 & 1.30 & 8.43 & 2.64 \\
\hline \multirow[t]{3}{*}{$\mathrm{C}$} & 5 & 7.99 & 4.64 & 32.79 & 9.06 & 19.69 & 9.56 \\
\hline & 10 & 7.70 & 2.99 & 24.41 & 6.56 & 16.48 & 7.19 \\
\hline & 15 & 9.50 & 3.84 & 45.15 & 10.06 & 29.15 & 14.35 \\
\hline
\end{tabular}

(Poleto and Merten, 2006; Wiesinieski, 2009). According to Messias (2008), variations in grain size of the sediments may be related to soil eroded and transported from the watershed into the water bodies which are presented as vectors of particles that react with existing contaminants and the transported to the aquatic environment.

The CEC highest value was found at point $\mathrm{B}$ at the deeper layer, where the higher clay content was observed $(13.56 \%)$. At all points CEC values greater than $5 \mathrm{cmol} \mathrm{dm}^{-3}$ were observed which leads to high cation exchange capacity (Cotta et al., 2006).

According to Bocalon (2007), sediments containing organic matter $(\mathrm{OM})$ above $10 \%$ are considered organics and below this value are considered minerals. Therefore, can be said that all samples has mineral sediment characteristics, since the OM content ranged from 0.69 to $2.64 \%$. The organic matter affects the chemical speciation of the metal ions by controlling its bioavailability and toxicity in aquatic environments, since metal has complexation sites (Lombardi et al., 2005)

The $\mathrm{pH}$ of the sediment interferes with the mobility of some metals, for example nickel, prevails in insoluble form in the sediment at $\mathrm{pH}$ above 6 (Zanello, 2006). Most of the results of the $\mathrm{pH}$ measurements were above 6 , only in point $\mathrm{B}$ at the height of $15 \mathrm{~cm}$ the measured $\mathrm{pH}$ was equal to 5.33. The results obtained do not completely agree with the literature, since although most $\mathrm{pH}$ values obtained were higher than 6 , the bioavailability compared with the pseudo-total content was greater than $30 \%$ in $78 \%$ of observations.

As previously mentioned the metal associated with the sediment is not necessarily bioavailable to aquatic biota as they may be associated with certain particles and are unavailable to the ecosystem (Poleto, 2008). So, besides the pseudo-total form, the metals were evaluated in bioavailable form because the water soluble and exchangeable fractions are considered readily mobile and available (Meurer, 2006).

\subsection{Chromium}

According to Zanello (2006), the phytotoxic concentrations of chromium in soil are in the range of $75-100 \mathrm{mg} \mathrm{kg}^{-1}$. The classification of the CONAMA Resolution 344/04 (Brasil, 2004) says chromium concentrations up to 
$37.3 \mathrm{mg} \mathrm{kg}^{-1}$ are considered Level 1, harmless to biota. The only point that exceeds this limit was point $\mathrm{C}$ at the depth of $15 \mathrm{~cm}$ with $45.15 \mathrm{mg} \mathrm{kg}^{-1}$, however, it does not reach the Level 2, considered a potential hazard to biota (concentrations over $90 \mathrm{mg} \mathrm{kg}^{-1}$ ). Still, according to Cotta (2003), chromium (III) does not migrate significantly to natural systems, being easily precipitated and adsorbed by the sediment. The high correlation coefficient $\left(\mathrm{R}^{2}=0.86\right)$ observed between chromium and the clay content shows the adsorption of chromium by clay (Figure 2).

\subsection{Lead}

In general, it was observed an increase of lead concentration in depth. According to Conceição (2005), this behavior contradicts the geochemical characteristics of this metal, which is of little mobility. Thus, the presence of lead in depth may be correlated to the earlier contamination. Following the guidance of 344/04 Resolution CONAMA (Brasil, 2004), all values are below Level 1 (35 $\left.\mathrm{mg} \mathrm{kg}^{-1}\right)$, considered unlikely to cause adverse effects to biota.

\subsection{Nickel}

The nickel content in the sediment found in points $B$ at $10 \mathrm{~cm}$ depth $\left(20.69 \mathrm{mg} \mathrm{kg}^{-1}\right)$, and $\mathrm{C}$ at 5 and $15 \mathrm{~cm}$ depth (19.69 mg kg-1 and $\left.29.15 \mathrm{mg} \mathrm{kg}^{-1}\right)$ are above the value considered Level $1\left(18 \mathrm{mg} \mathrm{kg}^{-1}\right)$ to the CONAMA resolution 344/04 (Brasil, 2004), but are still below the amount required to Level 2 (35.90 $\mathrm{mg} \mathrm{kg}^{-1}$ ) which can provide probable damage to the biota. The other values are found below the maximum value to be considered Level 1 .

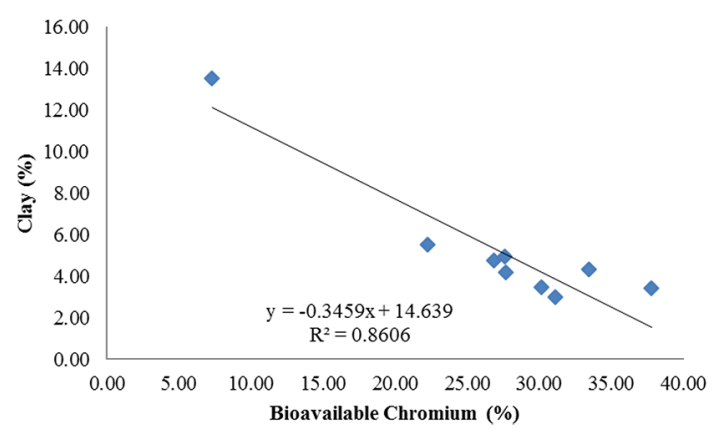

Figure 2. Graphic content Clay x Bioavailable Chromium.
According to Magalhães (2008), the bioavailable fraction of metals is the sum of exchangeable, soluble and easily adsorbed fractions, since the metals move among themselves, according to the physicochemical characteristics of the sediments. Therefore, the high occurrence of metals in the sediment does not mean harm to aquatic biota, as several factors can interfere with their bioavailability (Poleto, 2008). Figure 3 shows the proportion between bioavaliable and pseudo-total forms of each metal at the sample sites in depth.

The bioavailability of metals showed no behavior as described in the literature (Cotta et al., 2006) since all points had values above $5 \mathrm{cmol}_{\mathrm{c}} \mathrm{dm}^{-3}$ and some metals, as lead for example, reached $78.82 \%$ bioavailability.

It was observed also in the vicinity of the stream Luiz Rau disorderly occupation obstructing the stream and causing overflows at various points in its course. There are various ongoing works in the stream, such as the construction of urban rail train, which is affecting the flow of the stream in several ways, including the composition and behavior of sediment. Water is important for the transport stream bed sediments, so the urbanization interferes in the formation of sediment as well as for their behavior as heterogeneous.

\section{Conclusions}

With the exception of cadmium, all metals evaluated were found in all sampled points and depths, observed a strong anthropic action at points $\mathrm{B}$ and $\mathrm{C}$, where the highest concentrations of the metals nickel and lead occurred.

Despite being a source with a lower anthropogenic contribution, at point $\mathrm{A}$, is observed total chromium concentration, higher than those at point $\mathrm{B}$, signaling to early degradation of the site.

The high proportion of metals in bioavailable form and the increasing lead contents in depth, even considering the relatively high CEC values, points to the need for additional assessments that include the calculation of the rate of sedimentation of the stream and studies of sequential extraction of metals.

The studies were framed in standard CONAMA 344/04 (Brasil, 2004) for dredged materials in Brazilian waters, which are based in the Dutch and Canadian standards. It must be said that there are gaps in the Brazilian standard that

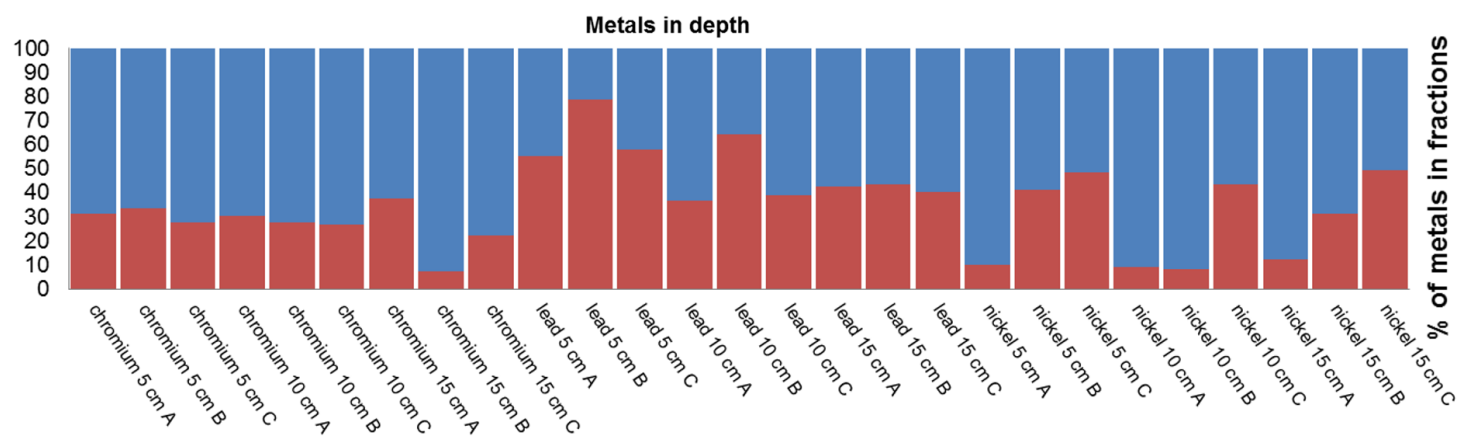

Figure 3. Graph of the bioavailability of metals in the sampled sites $-\bullet$ Bioavailable $\bullet$ Pseudo-total. 
could be reviewed. One of the main points is the observed concentration range between different classification levels and the lack of specifics on bioavailability.

\section{References}

ABREU, C.A., ABREU, M.F. and BERTON, R.S., 2002. Análise química de solo para metais pesados. In: SOCIEDADE BRASILEIRA DE CIÊNCIA DO SOLO. Tópicos em ciência do solo. Viçosa: SBCS, vol. 2, pp. 645-692.

BAIRD, C. and CANN, M., 2011. Química ambiental. 4th ed. Porto Alegre: Bookman. $622 \mathrm{p}$.

BOCALON, T.S., 2007. Estudos de sedimentos do rio Passaúna, com ênfase na determinação de metais pesados. Curitiba: Centro Universitário Positivo, 101 p. Dissertação de Mestrado em Gestão Ambiental.

BRASIL. Conselho Nacional do Meio Ambiente - CONAMA, 2004. Resolução $n^{\circ} 344$, de 25 de março de 2004. Estabelece as diretrizes gerais e os procedimentos mínimos para a avaliação do material a ser dragado em águas jurisdicionais brasileiras, e dá outras providências. Diário Oficial da República Federativa do Brasil. Brasília. 7 abr. pp. 56-57.

COMITE DE GERENCIAMENTO DA BACIA HIDROGRÁFICA DO RIO DOS SINOS - COMITESINOS [online], 2011. [viewed 5 April 2011]. Available from: http://www.comitesinos.com.br

CONCEIÇÃO, C.O., 2005. Contaminação dos aterros urbanos por metais pesados no município de Rio Grande - RS. Porto Alegre: Universidade Federal do Rio Grande do Sul, 108 p. Dissertação de Mestrado em Oceanografia Física, Química e Geologia.

COSTA, J.B. and ESPÍNDOLA, E.L.G., 2000. Avaliação ecotoxicológica da água e sedimento em tributários do reservatório de Barra Bonita (Médio Tietê Superior, SP). In: E.L.G. ESPÍNDOLA, C.M.R.B. PASCHOAL, O. ROCHA, M.B.C. BOHRER and A.L. OLIVEIRA NETO, orgs. Ecotoxicologia, perspectivas para o século XXI. São Carlos: Rima, pp. 75-93.

COTTA, J.A.O., 2003. Diagnóstico ambiental do solo e sedimento do parque estadual turístico do Alta Ribeira (PETAR). São Paulo: Universidade de São Paulo, 130 p. Dissertação de Mestrado em Ciências.

COTTA, J.A.O., REZENDE, M.O.O. and PIOVANI, M.R., 2006. Avaliação do teor de metais em sedimento do Rio Betari no Parque Estadual Turístico do Alto Ribeira - PETAR, São Paulo, Brasil. Quimica Nova, vol. 29, no. 1, pp. 40-45. http://dx.doi. org/10.1590/S0100-40422006000100009.

EMPRESA BRASILEIRA DE PESQUISA AGROPECUÁRIA - EMBRAPA, 1997. Manual de métodos de análise de solo. Rio de Janeiro: EMBRAPA/CNPS. 212 p.

FUNDAÇÃO ESTADUAL DE PROTEÇÃO AMBIENTAL - FEPAM [online], 2011. [viewed 2011 May 2011]. Available from: http://www.fepam.rs.gov.br/qualidade

ISHIKAWA, D. N., NOALE, R.Z., OHE, T.H.K., SOUZA, E.B.R., SCARMÍNIO, I.S., BARRETO, W.J., and BARRETO, S.R.G., 2009. Avaliação do risco ambiental em sedimento dos lagos do riacho Cambé, em Londrina, pela distribuição de metais. Química Nova, vol. 32, no. 7, pp. 1744-1749.

LOMBARDI, A.T., HIDALGO, T.M.R. and VIEIRA, A.A.H., 2005. Cooper complexing properties of dissolved organic materials exuded by the freshwater microalgae Scenedesmus acuminatus
(Chlorophyceae). Chemosphere, vol. 60, no. 4, pp. 453-459. http:// dx.doi.org/10.1016/j.chemosphere.2004.12.071. PMid:15950037.

MAGALHÃES, M.O.L., 2008. Avaliação do potencial de espécies de eucalipto na remediação de áreas contaminadas com metais pesados. Rio de Janeiro: Universidade Federal Rural do Rio de Janeiro, 58 p. Dissertação de Mestrado em Ciências.

MESSIAS, T.G., 2008. Influência da toxicidade da água e do sedimento dos rios São Joaquim e Ribeirão Claro na bacia do Corumbataí. São Paulo: Universidade de São Paulo, 125 p. Dissertação de Mestrado em Ciências.

MEURER, E.J., 2006. Fundamentos de química do solo. 3rd ed. Porto Alegre: Evangraf. 285 p.

MOZETO, A.A., SILVÉRIO, P.F., DE PAULA, F.C.F., BEVILACQUA, J.E., PATELLA, E. \& JARDIM, W.F., 2003. Weakly-bound metals and total nutrient concentrations of bulk sediments from some water reservoirs in São Paulo State, SE Brazil. In: M. MANAWAR, ed. Sediment quality assessment and management: insight and progress. New Delhi: Goodwords, pp. 221-239.

PICKERING, W.F., 1986. Metal ion speciation: soils and sediments (a review). Ore Geology Reviews, vol. 1, no. 1, pp. 83-146. http:// dx.doi.org/10.1016/0169-1368(86)90006-5.

POLETO, C. and MERTEN, G.H., 2006. Qualidade dos sedimentos. Porto Alegre: ABRH. 397 p.

POLETO, C., 2008. Ambiente e sedimentos. Porto Alegre: ABRH. 404 p.

QUINÁGLIA, G.A., 2006. Caracterização dos niveis basais de concentração de metais nos sedimentos do sistema estuarino da Baixada Santista. São Paulo: Universidade de São Paulo, 239 p. Tese de Doutorado.

RODRIGUES, M.L.K., 2007. Origem, distribuição e mobilidade potencial de metais pesados em ambiente fluvial impactado por curtumes. Porto Alegre: Universidade Federal do Rio Grande do Sul, 256 p. Tese de Doutorado em Geociências.

SERVIÇO DE ÁGUA E ESGOTO DE NOVO HAMBURGO COMUSA [online], 2011 [viewed 8 April 2011]. Available from: http://www.comusa.com.br

SILVA, M.R.C., 2002. Estudo de sedimentos da bacia hidrográfica do Moji-Guaçu, com ênfase na determinação de metais. São Paulo: Universidade de São Paulo, 113 p. Dissertação de Mestrado em Ciências.

SIQUEIRA, G.W. and BRAGA, E.S., 2000. Avaliação da dinâmica e da biodisponibilidade de $\mathrm{Zn}, \mathrm{Ni}$, Co e $\mathrm{Pb}$ para a biota a partir de sedimentos da plataforma continental do Amapá, nordeste da Amazônia. In: E.L.G. ESPÍNDOLA, C.M.R.B. PASCHOAL, O. ROCHA, M.B.C. BOHRER and A.L. OLIVEIRA NETO, orgs. Ecotoxicologia, perspectivas para o século XXI. São Carlos: Rima, pp. 241-265.

TEDESCO, J.M., GIANELLO, C., BISSANI, C.A., BOHNEN, H., and VOLKWESS, S.J., 1995. Análise de solo, plantas e outros materiais. 2nd ed. Porto Alegre: UFRGS. 174 p. Boletim Técnico, no. 5.

TUCCI, C.E.M., 2002. Hidrologia. 2nd ed. Porto Alegre: Editora da Universidade UFRGS/ABRH. 943 p.

UNITED STATES ENVIRONMENTAL PROTECTION AGENCY - EPA, 1996. Method 3050b: acid digestion of sediments, sludges, and soils. Washington: EPA. 
WIESINIESKI, J.A., 2009. Estudos de mecanismos de retenção de espécies metálicas no sedimento das lagoas de decantação do aterro controlado do Botuquara. Ponta Grossa: Universidade Estadual de Ponta Grossa, 120 p. Dissertação de Mestrado em Química Aplicada.

YU, K.C., TSAI, L.J., CHEN, S.H. and HO, S.T., 2001. Chemical binding of heavy metals in anoxic river sediments. Water Research, vol. 35, no. 17, pp. 4086-4094. http://dx.doi.org/10.1016/ S0043-1354(01)00126-9. PMid:11791838.

ZANELLO, S., 2006. Caracterização mineralógica e avaliação dos teores de $\mathrm{Cr}, \mathrm{Ni}, \mathrm{Cu}$, Zn e Pb dos solos do entorno do aterro sanitário da Caximba em Curitiba (PR). Curitiba: Universidade Federal do Paraná, 90 p. Dissertação de Mestrado em Ciência do Solo. 